\title{
Pancreatic Duct Stricture That Rapidly Progressed to Pancreatic Ductal Adenocarcinoma and Formed a Mass within 3 Months: A Case Report
}

\author{
Shin Kato $^{a} \quad K^{2}$ ji Chinen ${ }^{a}$ Susumu Shinoura ${ }^{a} \quad$ Fumihito Kunishima $^{b}$ \\ aDepartment of Gastroenterology, Okinawa Prefectural Chubu Hospital, Uruma, Japan; \\ ${ }^{\text {b}}$ Department of Pathology, Okinawa Prefectural Chubu Hospital, Uruma, Japan
}

\section{Keywords}

Pancreatic duct stricture - Pancreatic duct dilatation - Carcinoma in situ - Growth rate - Rapid growth $\cdot$ Pancreatic ductal adenocarcinoma

\begin{abstract}
The natural growth rate of pancreatic carcinoma in situ with pancreatic duct stricture remains unclear. Herein, we present a case with pancreatic duct stricture that rapidly grew to form a mass lesion within 3 months. A 74-year-old woman was referred to us for the investigation of a pancreatic duct dilatation. Initial images did not reveal any clear mass lesions near the pancreatic duct stricture. Pancreatic juice cytology showed suspicious findings. Distal pancreatectomy was recommended; however, the patient refused to undergo surgical treatment at that time. Images taken 3 months later demonstrated a nodular pancreatic body mass which was identified as a moderately to poorly differentiated tubular adenocarcinoma. Previous reports have suggested that pancreatic carcinoma in situ and small pancreatic ductal adenocarcinoma require at least $1-2$ years to progress to an advanced mass. This case suggests that pancreatic
\end{abstract}




\section{Case Reports in Gastroenterology}

Case Rep Gastroenterol 2018;12:247-253

DOI: $10.1159 / 000488977$

(c) 2018 The Author(s). Published by S. Karger AG, Basel www.karger.com/crg

Kato et al.: Pancreatic Duct Stricture That Rapidly Progressed to PD Cancer

carcinoma in situ may grow rapidly and indicates a need for close follow-up in patients with pancreatic duct strictures, even if the pathological evidence is not confirmed.

(C) 2018 The Author(s)

Published by S. Karger AG, Basel

\section{Introduction}

Pancreatic duct (PD) stricture and dilatation without a mass lesion are known to be signs of pancreatic carcinoma in situ, and their appearance necessitates an intensive workup, including endoscopic sampling of pancreatic juice for cytology obtained via an endoscopic nasopancreatic drainage (ENPD) tube [1-3]. Almost all patients with suspected pancreatic carcinoma in situ undergo surgical resection because the prognosis for patients with pancreatic carcinoma in situ after surgical resection is better compared with the prognosis for those with invasive pancreatic ductal carcinoma [4]. A former report of a case series including 12 patients with pancreatic carcinoma in situ showed survival of all patients without recurrence for 6-78 months after surgical resection [5]. In addition, patients with pancreatic ductal adenocarcinoma less than $10 \mathrm{~mm}$ in size have a better prognosis after surgical resection, with a 5-year survival rate of over $80 \%$ [4].

Therefore, there are few follow-up reports on pancreatic carcinoma in situ with PD stricture and small pancreatic ductal adenocarcinoma less than $10 \mathrm{~mm}$ in size, and the natural growth rate of these tumors remains unclear. There is only one report describing the natural growth rate of pancreatic carcinoma in situ till date [6], as well as one follow-up report of the natural growth rate of small pancreatic ductal adenocarcinomas less than $10 \mathrm{~mm}$ in size [7]. Hence, reports of close follow-ups in cases of PD stricture, suspected to be carcinoma in situ, and observation of the natural growth rate are important.

Here, we present the case of a patient with PD stricture that rapidly grew to form an advanced mass lesion within 3 months.

\section{Case Presentation}

A 74-year-old Japanese woman with a history of glioma was referred to us for the investigation of a PD dilatation that was incidentally detected during an annual health check. She had no specific symptoms at the time of referral. Physical examination revealed no remarkable findings. Initial laboratory data did not show any abnormalities, including tumor markers (Table 1). Abdominal enhanced computed tomography (CT) demonstrated a PD stricture on the pancreatic body and a PD dilatation on the pancreatic tail; however, a clear mass lesion was not observed (Fig. 1a). Endoscopic ultrasonography revealed a dilated PD, but a hypoechoic mass was not detected. Magnetic resonance cholangiopancreatography showed an intensity defect in the pancreatic body duct (Fig. 2a) and a pancreatic divisum. Endoscopic retrograde pancreatography was performed, and seven pancreatic juice cytology specimens were obtained using an ENPD tube via the minor papilla. Four specimens showed features suspicious of malignancy (Fig. 3a); thus, a distal pancreatectomy was strongly recommended to the pa- 
tient because carcinoma in situ was suspected. However, the patient refused to undergo surgical resection at that time without a definite pathological diagnosis. The patient refused to undergo repeated ENPD cytology and requested close follow-up by imaging.

On follow-up CT imaging conducted 3 months later, a 2-cm delayed enhanced mass lesion was observed near the PD stricture (Fig. 1b). Follow-up endoscopic ultrasonography showed a hypoechoic nodular mass lesion (Fig. 2b). The patient finally agreed to undergo surgical resection, and distal pancreatectomy was performed.

The resected specimen showed a 24-mm demarcated solid mass that was identified as a moderately to poorly differentiated tubular adenocarcinoma (Fig. 3b-d). Part of the solid lesion contained a scirrhous growth component (Fig. 3d). Lymphatic invasion (Fig. 3e) and moderate neural (Fig. 3f) and venous invasion (Fig. 3g) were observed. Lymph node metastasis was present. The pathological diagnosis was carcinoma of the pancreas with lymph node metastasis, pT3N1M0, G3, stage IIB (UICC-7).

The postoperative course was uneventful, and the patient was discharged on the 20th postoperative day. The patient is doing well without recurrence 24 months postoperatively.

\section{Discussion}

Few studies have investigated the growth rate of pancreatic adenocarcinoma. Yu et al. [8] reported that the time required for pancreatic adenocarcinoma to progress from a T1 tumor to a T3 and T4 tumor is 1.06 and 1.19 years, respectively. Another study suggested that the mean volume doubling time for pancreatic adenocarcinomas is 151.7 days [9]. After analysis of 100 patients with histologically proven pancreatic ductal adenocarcinoma, using multidetector CT, Ahn et al. [10] reported that the growth rate and volume doubling time of untreated pancreatic adenocarcinoma correlate with the tumor size, suggesting that a small tumor tends to grow slowly. While the abovementioned studies suggested that small pancreatic adenocarcinomas tend to grow slowly, these studies included cases with masses over $10 \mathrm{~mm}$ in size.

Reports of the natural growth rate of pancreatic carcinoma in situ and small pancreatic ductal adenocarcinoma less than $10 \mathrm{~mm}$ in size are extremely rare, mainly due to the difficulty in detecting pancreatic carcinoma in situ and small adenocarcinoma because of the absence of symptoms and effective screening strategies. In addition, almost all cases of suspected pancreatic carcinoma in situ and small pancreatic ductal adenocarcinoma less than $10 \mathrm{~mm}$ in size undergo surgical resection because the prognosis after surgical resection is relatively better [4]. There is only one observational report of a case of pancreatic carcinoma in situ that slowly progressed to a 1-cm T1 tumor over the course of 29 months [6]. Similarly, only one study reported on the natural growth rate of a small pancreatic ductal adenocarcinoma of $7 \mathrm{~mm}$. It took 22 months for this mass to increase from 7 to $13 \mathrm{~mm}$, and the patient then underwent surgical resection [7] (Table 2).

Although the natural growth rate of carcinoma in situ to advanced pancreatic ductal adenocarcinoma is unknown, the abovementioned reports suggest it would occur over a period of 1-2 years. In our present patient, the development of a mass within 3 months showed clear and rapid progression.

The existence of a scirrhous component could potentially have caused the rapid cancer cell proliferation and lymph node metastasis [11] in the present case; however, the predictive 
factors associated with rapidly growing pancreatic adenocarcinoma remain unclear. Therefore, in all cases of PD stenosis and dilatation with suspected carcinoma in situ, close followup imaging and careful monitoring should be performed if a patient refuses to undergo surgical treatment. Additional cases will need to be evaluated to further understand the natural progression of carcinoma in situ to pancreatic ductal adenocarcinoma.

\section{Acknowledgements}

This case was presented at the Joint Conference of IAP/JPS/AOPA 2016 in Sendai.

\section{Statement of Ethics}

The authors have no ethical conflicts to disclose.

\section{Disclosure Statement}

The authors state that they have no conflict of interest.

\section{References}

1 Iiboshi T, Hanada K, Fukuda T, Yonehara S, Sasaki T, Chayama K. Value of cytodiagnosis using endoscopic nasopancreatic drainage for early diagnosis of pancreatic cancer: establishing a new method for the early detection of pancreatic carcinoma in situ. Pancreas. 2012 May;41(4):523-9.

2 Hanada K, Okazaki A, Hirano N, Izumi Y, Teraoka Y, Ikemoto J et al. Diagnostic strategies for early pancreatic cancer. J Gastroenterol. 2015 Feb;50(2):147-54.

3 Kato S, Zakimi M, Yamada K, Chinen K, Kubota T, Arashiro M et al. Efficacy of repeated cytology of pancreatic juice obtained by endoscopic nasopancreatic drainage tube for early diagnosis of pancreatic cancer: a case series including a case of carcinoma in situ. Clin J Gastroenterol. 2015 Aug;8(4):240-6.

4 Egawa S, Toma H, Ohigashi H, Okusaka T, Nakao A, Hatori T et al. Japan Pancreatic Cancer Registry; 30th year anniversary: Japan Pancreas Society. Pancreas. 2012 Oct;41(7):985-92.

5 Tsunoda T, Yamamoto Y, Kimoto M, Imai H, Iwamoto S, Kawasaki S et al. Staging and treatment for patients with pancreatic cancer. How small is an early pancreatic cancer? J Hepatobiliary Pancreat Surg. 1998;5(2):128-32.

6 Nakamura T, Masuda K, Harada S, Akioka K, Sako H. Pancreatic cancer: slow progression in the early stages. Int J Surg Case Rep. 2013;4(8):693-6.

7 Hisa T, Ohkubo H, Shiozawa S, Ishigame H, Takamatsu M, Furutake M et al. Growth process of small pancreatic carcinoma: a case report with imaging observation for 22 months. World J Gastroenterol. 2008 Mar;14(12):1958-60.

8 Yu J, Blackford AL, Dal Molin M, Wolfgang CL, Goggins M. Time to progression of pancreatic ductal adenocarcinoma from low-to-high tumour stages. Gut. 2015 Nov;64(11):1783-9.

9 Jang KM, Kim SH, Kim YK, Song KD, Lee SJ, Choi D. Missed pancreatic ductal adenocarcinoma: assessment of early imaging findings on prediagnostic magnetic resonance imaging. Eur J Radiol. 2015 Aug;84(8):1473-9.

10 Ahn SJ, Choi SJ, Kim HS. Time to Progression of Pancreatic Cancer: Evaluation with Multi-Detector Computed Tomography. J Gastrointest Cancer. 2017 Jun;48(2):164-169.

11 Nagakawa T, Kobayashi H, Ueno K, Ohta T, Kayahara M, Mori K et al. The pattern of lymph node involvement in carcinoma of the head of the pancreas. A histologic study of the surgical findings in patients undergoing extensive nodal dissections. Int J Pancreatol. 1993 Feb;13(1):15-22. 


\section{Case Reports in Gastroenterology}

\begin{tabular}{l|l}
\hline Case Rep Gastroenterol 2018;12:247-253 \\
\hline DOI: 10.1159/000488977 & $\begin{array}{l}\text { @ 2018 The Author(s). Published by S. Karger AG, Basel } \\
\text { www.karger.com/crg }\end{array}$ \\
\hline
\end{tabular}

Kato et al.: Pancreatic Duct Stricture That Rapidly Progressed to PD Cancer
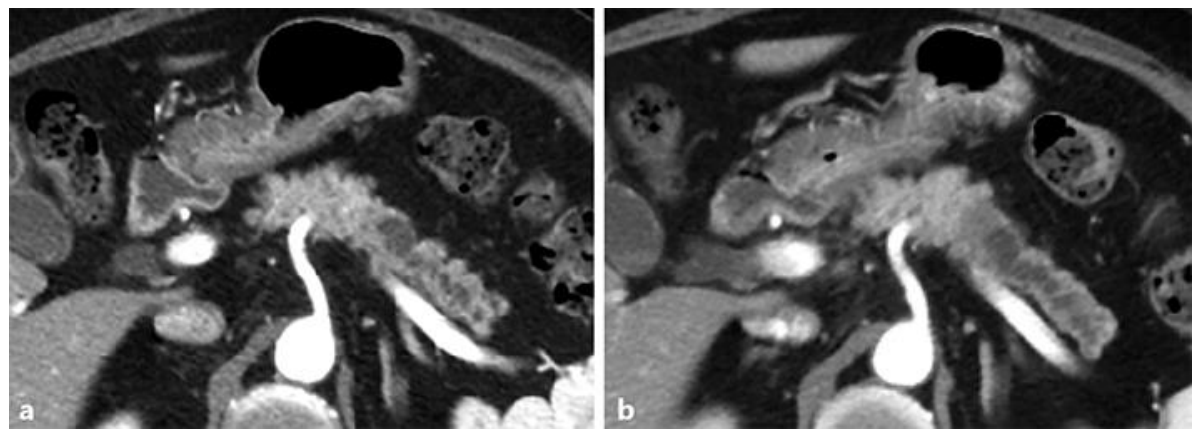

Fig. 1. a Initial enhanced computed tomography (arterial phase) image showing no mass lesion on the pancreatic body near the pancreatic duct stricture. b Three months later, follow-up computed tomography (arterial phase) revealed a nodular mass on the pancreatic body near the pancreatic duct stricture.
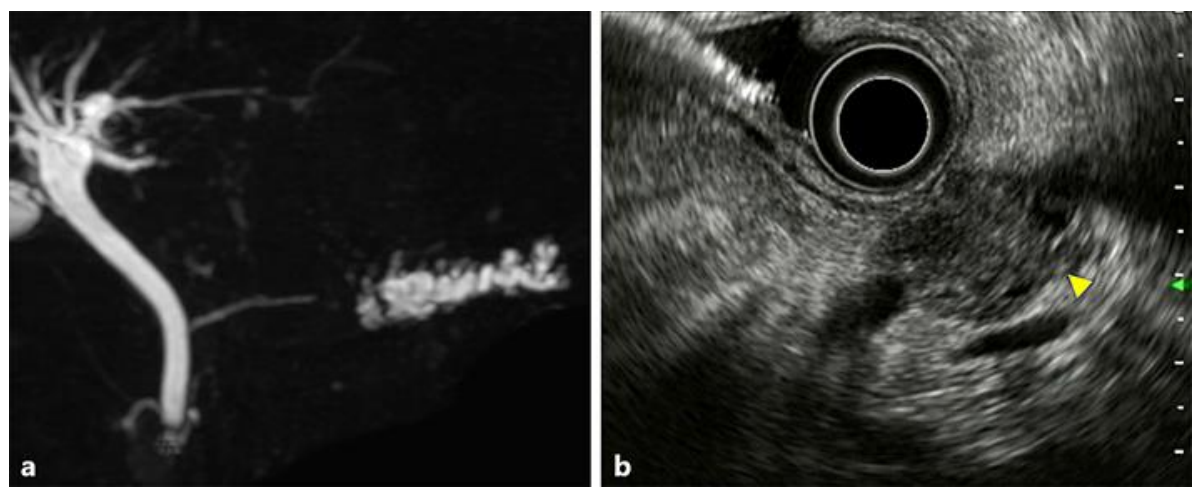

Fig. 2. a Magnetic resonance cholangiopancreatography showed an intensity defect of the main pancreatic duct. b Follow-up radial array endoscopic ultrasonography revealed a nodular mass near the pancreatic duct stricture (arrowheads). 


\section{Case Reports in Gastroenterology}
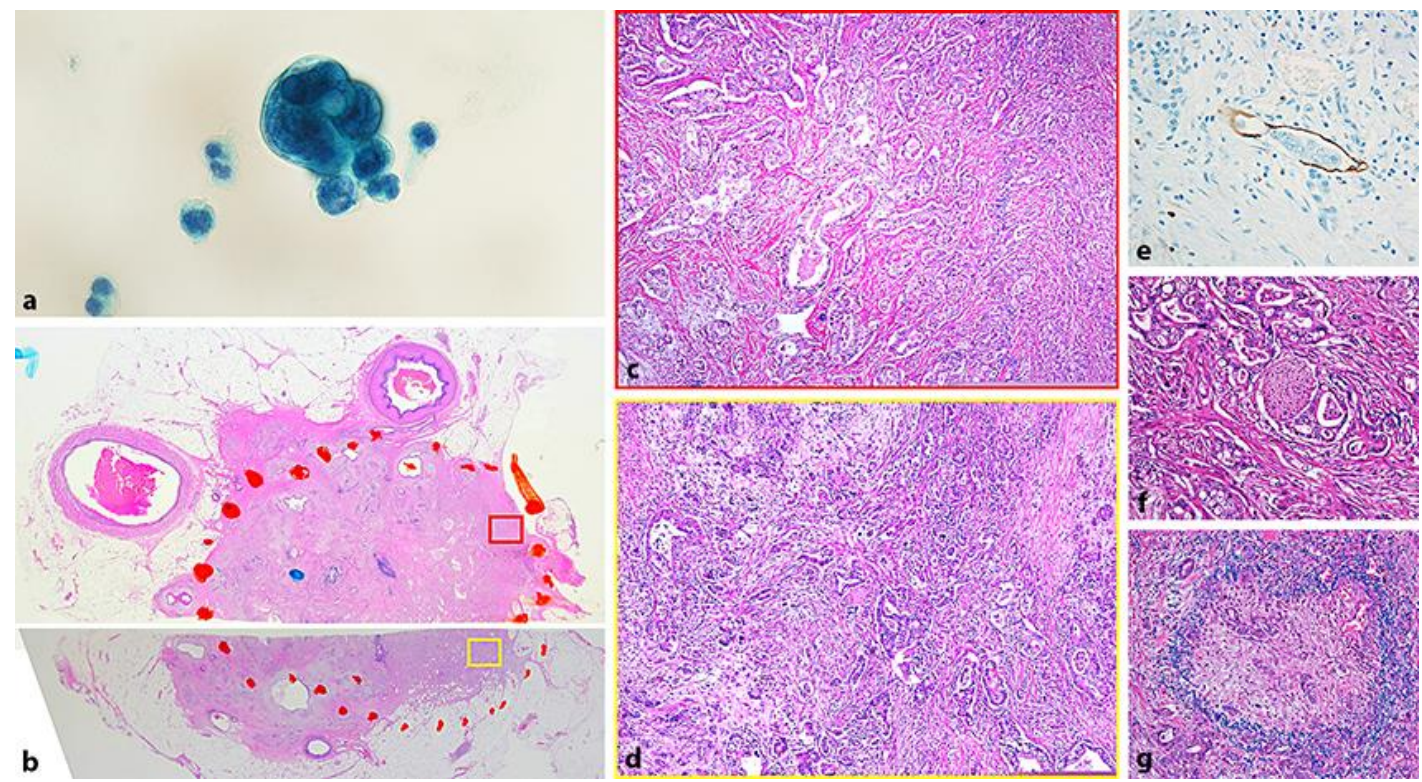

Fig. 3. a Pancreatic juice cytology showed features suspicious of malignancy (atypical cells with anisonucleosis). Papanicolaou stain. $\times 1,000$. b Victoria blue hematoxylin and eosin stain. $\times 10$. c, $\mathbf{d}$ The resected specimen was identified as moderately (c; Victoria blue hematoxylin and eosin stain; $\times 100$ ) to poorly (d; Victoria blue hematoxylin and eosin stain; $\times 100$ ) differentiated tubular adenocarcinoma. Some part of the solid lesion contained a scirrhous growth component (d). e Mild lymphatic invasion was observed. D2-40 stain. $\times 400$. $f$ Moderate neural invasion. Hematoxylin and eosin stain. $\times 200 . \mathbf{g}$ Moderate venous invasion. Azan stain. $\times 200$. 


\section{Case Reports in Gastroenterology}

\begin{tabular}{l|l}
\hline Case Rep Gastroenterol 2018;12:247-253 \\
\hline DOI: 10.1159/000488977 & $\begin{array}{l}\text { ( ) 2018 The Author(s). Published by S. Karger AG, Basel } \\
\text { www.karger.com/crg }\end{array}$ \\
\hline
\end{tabular}

Kato et al.: Pancreatic Duct Stricture That Rapidly Progressed to PD Cancer

Table 1. Initial laboratory data

$\begin{array}{ll}\text { Complete blood count } & \\ \text { WBC } & 6,880 / \mu \mathrm{L} \\ \mathrm{RBC} & 502 \times 104 / \mu \mathrm{L} \\ \mathrm{Hb} & 15.4 \mathrm{~g} / \mathrm{dL} \\ \mathrm{Plt} & 44.7 \times 104 / \mu \mathrm{L}\end{array}$

Coagulofibrinolysis

PT $126 \%$

\section{Tumor markers}

$\begin{array}{ll}\text { CEA } & 3.0 \mathrm{ng} / \mathrm{mL} \\ \text { CA } 19-9 & 6.1 \mathrm{U} / \mathrm{mL}\end{array}$

\section{Blood chemistry}

T.P.

T.Bil.

$6.6 \mathrm{~g} / \mathrm{dL}$

D.Bil.

$0.3 \mathrm{mg} / \mathrm{dL}$

AST

$0.1 \mathrm{mg} / \mathrm{dL}$

ALT

$25 \mathrm{IU} / \mathrm{L}$

ALP

$27 \mathrm{IU} / \mathrm{L}$

LDH

$235 \mathrm{IU} / \mathrm{L}$

Amylase

$167 \mathrm{IU} / \mathrm{L}$

BUN

$43 \mathrm{IU} / \mathrm{L}$

$\mathrm{Cr}$

$11.7 \mathrm{mg} / \mathrm{dL}$

Glu

$0.93 \mathrm{mg} / \mathrm{dL}$

$108 \mathrm{mg} / \mathrm{dL}$

Initial laboratory data revealed almost normal results including tumor markers.

Table 2. Characteristics of the pancreatic carcinoma in situ and the $<10$-mm-small pancreatic cancer

\begin{tabular}{llllllll}
\hline & $\begin{array}{l}\text { Initial mass } \\
\text { forming }\end{array}$ & $\begin{array}{l}\text { Loca- } \\
\text { tion }\end{array}$ & $\begin{array}{l}\text { Initial } \\
\text { diagnosis }\end{array}$ & $\begin{array}{l}\text { Follow-up } \\
\text { period, months }\end{array}$ & $\begin{array}{l}\text { Resec- } \\
\text { tion }\end{array}$ & $\begin{array}{l}\text { Final mass } \\
\text { volume, mm }\end{array}$ & $\begin{array}{l}\text { Final pathological diagnosis } \\
\text { (UICC7) }\end{array}$ \\
\hline $\begin{array}{l}\text { Hisa et al. [7] } \\
7 \mathrm{~mm}\end{array}$ & Body & BD-IPMN & 22 & (+) DP & 13 & Invasive ductal carcinoma \\
\hline $\begin{array}{l}\text { Nakamura } \\
\text { et al. [6] }\end{array}$ & $\begin{array}{l}\text { (-) } \\
\text { PD stricture }\end{array}$ & Head & $\begin{array}{l}\text { Carcinoma } \\
\text { in situ }\end{array}$ & 29 & (+) PDuo & 10 & $\begin{array}{l}\text { Invasive ductal carcinoma } \\
\text { (tub1) stage I A }\end{array}$ \\
\hline $\begin{array}{l}\text { Our case } \\
\text { (-) }\end{array}$ & BD stricture & Body & $\begin{array}{l}\text { Carcinoma } \\
\text { in situ }\end{array}$ & 3 & (+) DP & 24 & $\begin{array}{l}\text { Invasive ductal carcinoma } \\
\text { (tub2 Por) stage II b }\end{array}$ \\
\hline
\end{tabular}

PD, pancreatic duct; BD-IPMN, branch duct-intraductal papillary mucinous neoplasm; DP, distal pancreatectomy; PDuo, pancreaticoduodenectomy. 